


\title{
THE DIFFERENCES OF PHYSICAL, CHEMICAL AND FATTY ACID PROFILE OF MEAT QUALITY OF MALE MUSCOVY (Cairina moschata) AND LOCAL DUCK (Anas plathyrinchos)
}

\author{
Ismoyowati, N. Iriyanti and S. A. Santosa \\ Faculty of Animal Science, University of Jenderal Soedirman, \\ Jl. dr. Soeparno, Karangwangkal, Purwokerto 53123, Central Java - Indonesia \\ Corresponding E-mail: moy.moyowati@gmail.com
}

Received October 16, 2012; Accepted November 27, 2012

\begin{abstract}
ABSTRAK
Penelitian ini bertujuan membandingkan perbedaan kualitas fisik, kimia dan profile asam lemak pada daging entog (itik manila) dan itik lokal lainnya (Magelang, Tegal dan Mojosari). Pada penelitian digunakan metode eksperimental, dengan rancangan percobaan Rancangan Acak Lengkap. Faktor bangsa digunakan sebagai perlakuan yaitu Itik Manila, Magelang, Tegal dan Mojosari yang diulang sebanyak 5 kali. Analisis variansi dan uji beda nyata jujur digunakan untuk menganalisis data. Hasil penelitian menunjukkan terdapat perbedaan kualitas fisik daging pada warna, $\mathrm{pH}$ dan susut masak, sedangkan daya ikat air dan keempukan tidak berbeda nyata. Kandungan nutrisi secara makro yaitu lemak dan kolesterol dan protein relatif sama, akan tetapi persentase asam lemaknya berbeda. Entog memiliki kandungan asam lemak tak jenuh rantai ganda lebih tinggi dibandingkan dengan itik lokal lainnya. Penelitian dapat disimpulkan bahwa daging entok memiliki kualitas fisik dan kimia relatif sama, akan tetapi profil asam lemaknya lebih baik dibandingkan dengan itik lokal lainnya. Daging itik manila lebih sehat dikonsumsi karena mengandung asam lemak tak jenuh rantai ganda lebih tinggi dibandingkan dengan itik lokal lainnya.
\end{abstract}

Kata kunci: Itik manila, itik lokal, kualitas daging, asam lemak

\begin{abstract}
This research was aimed to differentiate the meat physical, chemical and fatty acid profile quality in muscovy and other local ducks (Magelang, Tegal and mojosari). Completely Randomized Design was used in this study. Breed used as treatments was muscovy, Magelang, Tegal and Mojosari ducks repeated 5 times. Analysis of variance and honestly significant difference were used to analyze data. Result showed there were differences in physical quality of meat in the term of colour, $\mathrm{pH}$, and cooking loss, while water holding capacity and tenderness were relatively similar. Fat, cholesterol and protein were relatively similar. Muscovy duck has a higher polyunsaturated fatty acids (PUFAs) than the other local duck. In conclusion, the physical and chemical quality of meat of muscovy and other local ducks were silimar. Muscovy duck meat is healthier to consume due to a higher polyunsaturated fatty acids than the other local ducks.
\end{abstract}

Keywords: muscovy, local duck, meat quality, fatty acid

\section{INTRODUCTION}

Recent poultry breeding and selection is to increase meat production and quality. The different poultry breed between local species duck (Anasplathyrhinchos) and muscovy (Cairinamoschata) results in different meat production and quality. Duck is one of the most desirable poultry products owing to consumer's preference shift from chicken to duck. The meat of muscovy duck, khaki chambel, Pekin and the crossbred had a good market potential especially in Asian countries (Huda et al., 2011). Culver duck farm (2012) reported that skinless Pekin duck breast in $100 \mathrm{~g}$ meat had lower calories (140 kalvs165 kal), lower fat (2.5gvs $4 \mathrm{~g})$, and higher iron $(5 \mathrm{mg}$ vs $1 \mathrm{mg}$ ) than skinless chicken breast. Preserved dried duck has lower water content and higher protein than other meat products (Lorenzo et al., 2011). Dried skinless duck has the highest amino acid of lycin and leucine, then valine, followed by threonine and isoleucine. Dried duck 
is also the source of iron, zinc, copper and manganese (Lorenzo et al., 2011).

Fat in duck meat is higher than in chicken and turkey (Bae'za et al., 2000; 2002), it is contradiction with reported by Culver duck farm (2012). Chicken and turkey breast is $1-2 \%$ on average (Rabot, 1998), while in other order namely Anasplathyrhinchos, Cairinamoschata and the crossbred is relatively high, $2.26-7.57 \%$ (Chartrin et al., 2003). In Indonesia there are several female local ducks kept as layer namely Tegal, Magelang and Mojosari ducks. While the male duck for meat production is muscovy duck.

Different meat quality is influenced by the breed or the genetic of the duck. Meat quality is defined by the content of meat fat (intramuscular fat) that influences physical and sensory quality and nutrition content of meat (Ruiz et al., 2001). Intramuscular fat in various fowl species as reported by Chatrin et al. (2000) in pekin and muscovy is found different pectoralis in muscle $(2.3 \%$ vs $4.6 \%)$. The different fat content in water fowl is due to different lipoprotein lipase activity (LPL) (Davail et al., 2003). Different balance of lipogenesis muscle and oxidation of long chain fatty acid is the significant factor of different intramuscular fat in any species (Halloway et al., 2009) and within species (Gondret et al., 2004). This research studied the difference of physical, chemical and fatty acid profile quality of male muscovy (Cairinamochata) and local ducks (Anasplathyrinchos).

\section{MATERIALS AND METHODS}

Experimental method with Completely Randomized Design was applied. Ducks used as treatment comprised four types of duck with five times repetition. Materials used were muscovy and local ducks consisted of male Magelang, Tegal and Mojosariday old ducks, 25 birds each. Ducks were fed on feed with composition as shown in Table 1. Chemicals for meat chemical analysis and fatty acid profile, and the equipment used was a set of physical, chemical and meat fatty acid profile analysis.

Day old ducks were reared in brooder up to three weeks old. Feed was given ad libitum controlled with starter period feed use a chicken broiler starter (BR I). At four weeks old, ducks were put into treatment cage unit, each consisted of five birds and was repeated five times to make up 20 treatment units. Ducks were fed with grower period based on need, thus $100 \mathrm{~g}$ from 4 weeks old and increased to $150 \mathrm{~g}$ at 8 weeks old. Water was given ad libitum.

The parameters observed in this study were physical quality of the meat duck consisted of skin and meat colour, $\mathrm{pH}$, cooking loss (CL), tenderness and water holding capacity (WHC). The chemical properties were included meat fat, cholesterol, protein and fatty acid profiles $(\mathrm{C} 8=0)$, $\mathrm{C} 12=0, \mathrm{C} 14=0, \mathrm{C} 16=0, \mathrm{C} 16=1, \mathrm{C} 18=0, \mathrm{C} 18=1$, $\mathrm{C} 18=2, \mathrm{C} 18=3, \mathrm{C} 20=0$ and $\mathrm{C} 22=0$ ).

At 10 weeks old, one duck from each unit was slaughtered by Khoser method, followed by processing to obtain carcass that were scalding, defeathering, evisceration, non-carcass chopping and carcass scaling (Rose, 1997). Skin and meat colour was qualitatively observed. Meat sampling for physical, chemical quality and fatty acid profile test was taken from skinless leg and breast.

Physical and chemical meat quality was analyzed by taking sample on leg and breast. $\mathrm{pH}$ of the duck meat was measured using $\mathrm{pH}$ meter. Cooking loss (\%) was measured by placing the weighed duck meat sample, sealed in a plastic bag, in water bath (pre heated to $80^{\circ} \mathrm{C}$ ) for 1 hour (Honikel, 1998). The tenderness was measured using penetrometer,water holding capacity (WHC) was measured with filter paper press method (Honikel and Hamm, 1994). The analysis of meat protein and fat used AOAC method (1990); cholesterol level was measured with Lieberman and Burchard method; and fatty acid composition was measured with HPLC.

The data were subjected to Completely Randomized Design analysis of variance followed by Honestly Significant Difference (HSD).

\section{RESULT AND DISCUSSION}

\section{Physical Quality of Duck Meat}

Skin and meat color is one of physical quality indicator of fowl carcass. Fowl skin varies from cream to yellow. Result showed that skin and meat of muscovy duck is relatively brighter than the other ducks (Table 2). Darker color on local duck meat indicated higher hemoglobin and myoglobin than muscovy. Raw meat ranges from soft red to red due to hemoglobin and myoglobin content in muscle. The higher the myoglobine in muscle, the darker the meat color. When it was cooked, meat turns darker. Leg meat is darker than other parts especially breast (GuerreroLegarreta, 2010). Chartrinet al. (2006) reported that highly fatty duck breast had paler and more yellowish color. 
Table 1. Nutrition Composition and Content of Feed for Muscovy and Other Local Ducks as Starter and Grower Period

\begin{tabular}{lcc}
\hline Feed & Starter Feed & Grower Feed \\
\hline Corn & BR 1 & 47.0 \\
Fishmeal & & 8.0 \\
Rice bran & & 37.0 \\
Meat bone meal & \multicolumn{2}{c}{5.0} \\
Corn cob meal & \multicolumn{2}{c}{2.0} \\
Premix & \multicolumn{2}{c}{1.0} \\
Total & \multicolumn{2}{c}{100} \\
Feed Nutrition Content & & \\
Crude protein $(\%)$ & 21 & 15.068 \\
ME (kcal/kg) & 3000 & 2806 \\
Crude fiber $(\%)$ & 5 & 7.042 \\
Crude fat $(\%)$ & 5 & 4.322 \\
Ca (\%) & 1 & 1.805 \\
P $(\%)$ & 0.9 & 1.221 \\
\hline Cal
\end{tabular}

Calculation based on NRC (1994)

Result of physical quality measurement of muscovy and various local ducks showed different $\mathrm{pH}$ and cooking loss (CL), while water holding capacity (WHC) and tenderness were relatively the same (Table 3). The highest of $\mathrm{pH}$ average was on the leg of muscovy duck (6.520 \pm 0.247$)$, while the lowest was on the breast of Tegal duck (6.006 \pm 0.036$)$. A faster decline on $\mathrm{pH}$ in local duck meat indicated the forming of lactic acid due to faster glycogenesis in muscle than that of muscovy duck. The decline depended on the supply of glycogen and glucose on the dying fowl. The rate of $\mathrm{pH}$ decline depends on muscle physiology, type of muscle and type of animal. Meat acidity is affected by lactic acid, in which pH 7 barely had lactic acid on meat, while $\mathrm{pH} 5.5$ had approximately $1 \%$ of lactic acid (Soeparno, 2005). $\mathrm{pH}$ value in all duck strain was at the acceptable level and the meat was not pale color (PSE). Postmortem influenced $\mathrm{pH}$ decline and water holding capacity (Huff-Lonergan and Lonergan, 2005; Adzitey, 2011).

Cooking loss is the loss of water content in boiling process. The different cooking loss was due to intramuscular fat disposition that restrains the loss of meat juice during cooking, although the more fatty meat will lose more fat as well. Result showed that breast meat of muscovy had the highest cooking loss than the other ducks. There was negative correlation between $\mathrm{pH}$ and cooking loss. This indicated that as the $\mathrm{pH}$ decreased, the cooking loss increased (Table 3). Botha et al. (2007) reported that there was a significant correlation $(\mathrm{r}=-0.278)$ between $\mathrm{pH}$ and cooking loos of the ostrich carcasses throughout the 21-days aging period.

Water holding capacity is the ability of meat to biund its water or the additional water during outside treatment such as cutting, heating, griunding, and pressing of meat (Soeparno, 2005). WHC is a term used to describe muscle ability to biund water in certain condition and therefore, it is always related to sensory characteristics of meat like juiciness and taste. Water in muscle is divided into three water compartments, namely, water that is chemically bound by muscle protein as much as $4-5 \%$ as the first monomolecular layer; a less strong bound water as the second layer of water molecule toward hydrolytic group as much as $4 \%$, and this second layer will be bound by protein when the vapor pressure increases; the third layer is free water molecules among protein molecules around 10\% (Pena et al., 2009). Result of WHC measurement in four types of ducks showed a similar value 75.496$77.698 \%$, in which the higher the WHC, the better

Table 2.Meat and Skin Color of Muscovy and Other Local Ducks

\begin{tabular}{|c|c|c|c|c|c|c|c|c|}
\hline \multirow{2}{*}{ Traits } & \multicolumn{2}{|c|}{ Muscovy } & \multicolumn{2}{|c|}{ Magelang } & \multicolumn{2}{|c|}{ Tegal } & \multicolumn{2}{|c|}{ Mojosari } \\
\hline & Breast & Leg & Breast & Leg & Breast & Leg & Breast & Leg \\
\hline Meat Color & $\begin{array}{l}\text { Bright } \\
\text { Soft Red }\end{array}$ & Darker & Dark Red & Dark Red & Dark Red & Dark Red & Dark red & Dark red \\
\hline Skin Color & $\begin{array}{l}\text { Bright } \\
\text { Cream }\end{array}$ & $\begin{array}{l}\text { Bright } \\
\text { Cream }\end{array}$ & Cream & Cream & Cream & Cream & Cream & Cream \\
\hline
\end{tabular}


Tabel 3. Physical Quality of Muscovy and Other Local Ducks

\begin{tabular}{llcccc}
\hline \multicolumn{1}{c}{ Animal } & Body Part & $\mathrm{pH}$ & $\mathrm{CL}(\%)$ & WHC $(\%)$ & $\begin{array}{c}\text { Tenderness } \\
(\mathrm{mm} / \mathrm{g} / \mathrm{sec} .\end{array}$ \\
\hline Muscovy & Breast & $6.108 \pm 0.106^{\mathrm{a}}$ & $41.651 \pm 1.955^{\mathrm{b}}$ & $75.767 \pm 4.106$ & $0.538 \pm 0.032$ \\
& Leg & $6.520 \pm 0.247^{\mathrm{b}}$ & $38.558 \pm 3.646^{\mathrm{b}}$ & $76.631 \pm 3.100$ & $0.489 \pm 0.031$ \\
Tegal & Breast & $6.006 \pm 0.036^{\mathrm{a}}$ & $33.870 \pm 1.284^{\mathrm{a}}$ & $75.615 \pm 2.470$ & $0.619 \pm 0.205$ \\
& Leg & $6.226 \pm 0.063^{\mathrm{a}}$ & $31.516 \pm 3.469^{\mathrm{a}}$ & $75.496 \pm 2.344$ & $0.507 \pm 0.055$ \\
Magelang & breast & $6.240 \pm 0.175^{\mathrm{a}}$ & $38.774 \pm 2.137^{\mathrm{b}}$ & $77.698 \pm 0.692$ & $0.494 \pm 0.068$ \\
& Leg & $6.320 \pm 0.131^{\mathrm{a}}$ & $40.899 \pm 2.730^{\mathrm{b}}$ & $75.794 \pm 2.310$ & $0.477 \pm 0.047$ \\
Mojosari & Breast & $6.010 \pm 0.032^{\mathrm{a}}$ & $34.657 \pm 2.020^{\mathrm{a}}$ & $77.207 \pm 2.016$ & $0.592 \pm 0.039$ \\
& Leg & $6.433 \pm 0.133^{\mathrm{ab}}$ & $32.264 \pm 1.759^{\mathrm{a}}$ & $76.068 \pm 1.451$ & $0.580 \pm 0.055$ \\
Intra breed & & $\mathrm{P}>0.05$ & $\mathrm{P}<0.05$ & $\mathrm{P}>0.05$ & $\mathrm{P}>0.05$ \\
Inter part- & & $\mathrm{P}>0.01$ & $\mathrm{P}<0.05$ & $\mathrm{P}>0.05$ & $\mathrm{P}>0.05$ \\
intra breed & & & & &
\end{tabular}

Different superscript in the same column shows significant difference $(\mathrm{P}<0.05)$

Tabel 4. Fat, Cholesterol and Protein Content in Muscovy and Other Local Ducks

\begin{tabular}{lrrrrc}
\hline \multicolumn{1}{c}{ Meat Chemical } & \multicolumn{1}{c}{ Muscovy } & \multicolumn{1}{c}{ Tegal } & \multicolumn{1}{c}{ Magelang } & \multicolumn{1}{c}{ Mojosari } & Significance \\
\hline Fat $(\%)$ & $2.586 \pm 0.401$ & $4.880 \pm 1.993$ & $4.181 \pm 1.097$ & $3.422 \pm 0.145$ & $\mathrm{P}>0.05$ \\
cholesterol $(\mathrm{mg} / \mathrm{g})$ & $1.249 \pm 0.098$ & $1.078 \pm 0.088$ & $1.034 \pm 0.143$ & $1.007 \pm 0.259$ & $\mathrm{P}>0.05$ \\
Protein $(\%)$ & $16.199 \pm 0.131$ & $17.683 \pm 1.517$ & $17.379 \pm 0.518$ & $17.679 \pm 1.131$ & $\mathrm{P}>0.05$ \\
\hline
\end{tabular}

the meat quality.

Meat tenderness in Muscovy and other local ducks shared a similar value in the average of $0.477-0.619 \mathrm{~mm} / \mathrm{g} / \mathrm{sec}$. Meat tenderness is affected by genetic factor, thus the breed or the species. Muscovy and other local ducks had similar tenderness value, because they had the fat content of meat relatively similar. Meat tenderness was affected by fat content, it was positively correlated with lipid levels (Chartrin $e t$ al. 2006). Tenderness is also one of the indicators of meat quality and palatability. Consumers prefer tenderer meat because of easier tooth penetration and chewing, while tougher meat is harder to pierce either by teeth or by needle.

\section{Chemical Quality of Duck meat}

Nutritional composition of duck depends on the breed and the strain of duck (Ramadhan et al., 2010). Analysis of variance result showed a relatively similar fat, cholesterol and protein content of meat in various local ducks (Table 4). Biologically, muscovy duck contains lower fat and protein than the other local ducks but the cholesterol is the highest. It indicated that duck breed had no effect on meat composition. Meat sample used in this research was skinless breast and leg so the fat content was lower than that of broiler, turkey, duck and quail according to USDA (2006) (Table 5). Other research reported that fat content in muscovy breast is $2.89 \mathrm{~g} / 100 \mathrm{~g}$ and in Pekin duck is $6.4 \mathrm{~g} / 100 \mathrm{~g}$ (Aronal et al., 2012). Indonesian local duck fed $19 \%$ protein and $3000 \mathrm{kcal} / \mathrm{mg}$ ME contains $6.16 \pm 1.29 \% \quad(6.16$ $\mathrm{g} / 100 \mathrm{~g})$ fat and $186 \pm 0.13 \mathrm{mg} / \mathrm{g}$ cholesterol (Ismoyowati and Sumarmono, 2011). The 
Tabel 5.Chemical Composition of Fowl Meat (g/100g)

\begin{tabular}{lrrrr}
\hline \multicolumn{1}{c}{ Component } & Broiler & Turkey & Duck & Quail \\
\hline Water & 74.6 & 72.5 & 70.8 & 74.4 \\
Ash & 1.0 & 0.8 & 1.2 & 1.1 \\
Protein & 12.1 & 13.7 & 12.8 & 13.1 \\
Fat & 11.1 & 11.9 & 13.8 & 11.1 \\
Carbohydrate & 1.2 & 1.1 & 1.4 & 1.4 \\
\hline
\end{tabular}

Source: USDA (2006)

Tabel 6. Fatty Aacid Profile of Muscovy and Other Local Ducks

\begin{tabular}{lcccc} 
& \multicolumn{4}{c}{ Relative Percentage of Fatty Acid Composition } \\
\cline { 2 - 5 } Acid & Muscovy & Tegal & Magelang & Mojosari \\
\cline { 2 - 5 } C8=0 & $0.154 \pm 0.060^{\mathrm{ab}}$ & $0.288 \pm 0.027^{\mathrm{b}}$ & $0.282 \pm 0.087^{\mathrm{b}}$ & $0.109 \pm 0.010^{\mathrm{a}}$ \\
$\mathrm{C} 12=0$ & $0.154 \pm 0.020^{\mathrm{ab}}$ & $0.288 \pm 0.002^{\mathrm{b}}$ & $0.282 \pm 0.002^{\mathrm{ab}}$ & $0.109 \pm 0.016^{\mathrm{a}}$ \\
$\mathrm{C} 14=0$ & $0.492 \pm 0.005$ & $0.539 \pm 0.112$ & $0.528 \pm 0.074$ & $0.369 \pm 0.091$ \\
$\mathrm{C} 16=0$ & $22.847 \pm 0.601^{\mathrm{b}}$ & $22.848 \pm 3.211^{\mathrm{b}}$ & $19.351 \pm 3.621^{\mathrm{ab}}$ & $16.217 \pm 1.046^{\mathrm{a}}$ \\
$\mathrm{C} 16=1$ & $2.439 \pm 0.010$ & $2.107 \pm 0.207$ & $2.346 \pm 0.153$ & $1.890 \pm 0.862$ \\
$\mathrm{C} 18=0$ & $9.053 \pm 0.162^{\mathrm{b}}$ & $6.076 \pm 0.906^{\mathrm{a}}$ & $6.500 \pm 0.175^{\mathrm{a}}$ & $5.750 \pm 0.359^{\mathrm{a}}$ \\
$\mathrm{C} 18=1$ & $36.223 \pm 0.219^{\mathrm{b}}$ & $28.250 \pm 5.120^{\mathrm{ab}}$ & $27.685 \pm 8.680^{\mathrm{ab}}$ & $22.443 \pm 3.396^{\mathrm{a}}$ \\
$\mathrm{C} 18=2$ & $14.597 \pm 1.267^{\mathrm{ab}}$ & $13.963 \pm 2.022^{\mathrm{ab}}$ & $19.251 \pm 5.269^{\mathrm{b}}$ & $10.220 \pm 0.744^{\mathrm{a}}$ \\
$\mathrm{C} 18=3$ & $0.124 \pm 0.007$ & - & & - \\
$\mathrm{C} 20=0$ & $0.293 \pm 0.033^{\mathrm{b}}$ & - & $0.155 \pm 0.045^{\mathrm{a}}$ & $2.856 \pm 0.177^{\mathrm{b}}$ \\
$\mathrm{C} 22=0$ & $3.185 \pm 0.347^{\mathrm{a}}$ & $3.495 \pm 0.328^{\mathrm{a}}$ & $2.715 \pm 0.636^{\mathrm{a}}$ & $2.493 \pm 0.010^{\mathrm{a}}$ \\
\hline
\end{tabular}

Different superscript in the same column showed significant difference $(\mathrm{P}<0.05)$

differences on fat and cholesterol was due to different feed. Fat and cholesterol synthesis in cell through acetyl coenzyme A was influenced by fat and cholesterol content in the feed.

Protein in human is essential for growth, maintenance and repair of damage tissue, also as the source of energy without carbohydrate. Fat is an important energy source but has negative effect on health. Cholesterol is important for steroid hormone production, normal nerve function, formation of brain cell, cell membrane, vitamin D synthesis and many others. However, over consumed cholesterol causes atherosclerosis that leads to human death (Griffin, 1999). Endogen cholesterol synthesized in liver is three times higher than cholesterol from the consumed food (Okuyama et al., 2007).

\section{Fatty Acid Profile of Duck Meat}

Duck fatty acid profile is presented on Table 6 consisted of saturated fatty acid: C14:0, C16:0, C18:0; monounsaturated fatty acid: C14:1, C16:1, $\mathrm{C} 18: 1$ and polyunsaturated fatty acid: $\mathrm{C} 18: 2$, C18:3, C20:4, C20:6. The biggest proportion (\%) is oleic acid $(\mathrm{C} 18=1)$ on $22.443-36.223 \%$ in average, palmitic acid (C16=0) on 16.217- 
$22.848 \%$ in average and $\mathrm{C} 18=0$ on 10.220 $19.251 \%$ in average. The observed duck meat was skinless breast and leg. Cairinamoschata had the highest oleic acid proportion. This result is different from that of Kokoszyński et al. (2002); Wołoszyn et al. (2005); Kokoszynski and Bernacki (2010) reported that the higher fatty acid proportion on Pekin duck is palmitic acid which is harmful for human health.

Analysis of variance result showed significant difference on the composition of saturated and unsaturated fatty acid in muscovy and other local ducks (Table 6). Mojosari duck has the lowest unsaturated fatty acid than those of muscovy and other local ducks. Muscovy duck contained the highest monounsaturated fatty acid (MUFA) of other local ducks. Magelang duck contained the highest polyunsaturated fatty acid (C18:2). The C18:3 was detected in Muscovy, but not detected in other local ducks.

The different composition of fatty acid in fowl is due to breed and the feed (Bekerbauer et al., 2001). Duck meat composition is highly defined by the source of fatty feed, grains, plants and water creature in paddy field ecosystem where the ducks are reared, which also significantly affect the fatty acid composition (Coboset al., 2000). Fatty acid in different meat part has different composition as well, in which fowl white meat (breast meat) contains lower phospholipids and PUFA than fowl red meat (leg meat). Fatty acid composition is related to the type of muscle fiber (Wood et al., 2003)

\section{CONCLUSION}

Macro nutritional contents in meat of muscovy and other local ducks namely fat, cholesterol and fatty acid were similar but different in fatty acid percentage. Muscovy duck meat has a higher polyunsaturated fatty acid than the other local duck. Muscovy and other local ducks had different physical and chemical meat quality. Muscovy duck meat is healthier to consume due to a higher polyunsaturated fatty acid than the other local ducks.

\section{ACKNOWLEDGMENTS}

The author was grateful to Direktur Jenderal Pendidikan Tinggi and the Head of LPPM Unsoed for the funding in research of DIKTI Grant Competition based on the letter of agreement of grant competition year 2012 No:
2642/UN23.10/PN/2012 dated 30 March 2012.

\section{REFERENCES}

Adzitey, F. 2011. Effect of pre-slaughter animal handling on carcass and meat quality. Int. Food Res. 18: 484-490.

AOAC. 1990. Official Methods of Analysis. $15^{\text {th }}$ Edition. Association of Official Analytical Chemists, Arlington, Virginia.

Aronal, A.P., N. Huda and R. Ahmad.. 2012. Amino Acid and Fatty Acid Profiles of Peking and Muscovy Duck Meat. Int. J. Poult. Sci. 11(3):229-236.

Bae'za, E., C. Dessay, N. Wacrenier, G. Marche' and A. Listrat. 2002. Effect of selection for improved body weight and composition on muscle and meat characteristics in Muscovyduck. Br. Poult. Sci. 43:560-568.

Bae'za, E., M. R. Salichon, G. Marche, N. Wacrenier, B. Dominguez and J. Culioli. 2000. Effects of age and sex on the structural, chemical and technological characteristics of mule duck meat. Br. Poult. Sci. 41:300-307.

Beckerbauer, L.M., R. Thiel-Cooper, D.U. Ahn, J.L. Sell, F.C. Parrish Jr. and D.C. Beitz, 2001. Influence of two dietary fats on the composition of emu oil and meat. Poult. Sci. 80: 187-194.

Botha, S. St.,C., L.C. Hoffman and T.J. Britz. 2007. Physical meat quality characteristics of hot-deboned ostrich (Struthiocamelus var. domesticus) Muscularis gastrocnemius, pars interna during post-mortem aging. Meat Sci. 75: 709-718

Chartrin, P., J. Mourot, M. D. Bernadet, G. Guy, M. J. Duclos and E. Bae'za. 2003. Effect of genotype and force feeding on the intramuscular fat deposition in duck. Proc. 16th Eur. Symp. Qual. Poult. Meat, SaintBrieuc, France.ISPAIA, Ploufragan, France, 2003. P. 224-230.

Chartrin, P., M. D. Bernadet, G. Guy, J. Mourot, M. J. Duclos and E. Baéza. 2006. The effects of genotype and overfeeding on fat level and composition of adipose and muscle tissues in ducks. Anim. Res. 55:231-244.

Cobos, A., A. Veiga and O. Diaz, 2000.Chemical and fatty acid composition of meat and liver of wild ducks (Anas platyrhynchos). Food Chem. 68: 77-79.

Culver Duck Farm. 2012. Nutritional of white pekin duck vs chicken, turkey, pork and beef. 
http://www.culverduck.com/nutrition.asp. accessed on 12 December 2012.

Davail, S., N. Rideau, G. Guy, J. M. André, D. Hermier and R. Hoo-Paris. 2003. Hormonal and metabolic responses to overfeeding in three genotypes of ducks. Comp. Biochem. Physiol. 134A:707-715.

Gondret, F., J. F. Hocquette and P. Herpin. 2004. Age-related relationships between muscle fat content and metabolic traits in growing rabbits. Reprod. Nutr. Dev. 44:1-16.

Griffin BA. 1999. Lipoprotein atherogenicity: an overview of current mechanisms. Proc. Nutr. Soc. 58(1):163-169.

Guerrero-Legarreta, I. 2010.Handbook of poultry science and technology.John Wiley \& Sons, Inc., Hoboken, New Jersey.

Honikel, K.O. 1998. Reference methods for the assessment of physical characteristic of meat. Meat Sci. 49:447-457.

Honikel, K.O. and R. Hamm. 1994. Measurement of water-holding capacity, and juiciness. In A.M. Pearson, and T.R, Dutson (Eds.), Advances in Meat Research Vol 9. Glasgow: Blackie Academic and Professional, pp. 125161.

Holloway, G. P., C. R. Benton, K. L. Mullen, Y. Yoshida, L. A. Snook, X. X. Han, J. F. C. Glatz, J. F. Luiken, J. Lally, D. J. Dyck and A. Bonen. 2009. In obese rat muscle transport of palmitate is increased and is channeled to triacylglycerol storage despite an increase in mitochondrial palmitat oxidation. Am. J. Physiol. Endocrinol. Metab. 296:E738-E747.

Huda, N., AA. Putra and R. Ahmad. 2011. Potential application of duck meat for development processed meat product. Current Res. Poult. Sci. 1: 1-11.

Kokoszynski D, H. Korytkowska, M. Adamski and Z. Bernacki. 2002. Evaluation of slaughter traits and proportionof fatty acids in breast muscles of strain A55 and P77 ducks. RoczNauk Zoot suppl 16: 317-21.

Kokoszynski, D and Z. Bernacki. 2010. Comparison of some meat traits in ducks from two conservative flocks. ArchivTierzucht 53. 4: 484-493.
NRC. 1994. Requirements of poultry. $9^{\text {th }}$ Revised Ed. National Academic Science. Washington, D.C.

Okuyama H, T. Kobayashi and S. Watanabe. 1997. Dietary fatty acids the $n-6 / n-3$ balance and chronic elderly diseases: excess linoleic acid and relative $n$-3 deficiency syndrome seen in Japan. Prog Lipid Res 35(4):409-457.

Peña,F., A. Bonvillani, B. Freire, M. Juárez, J. Perea and G. Gómez. 2009. Effects of genotype and slaughter weight on the meat quality of CriolloCordobes and Anglonubian kids produced under extensive feeding conditions. Meat Science 83: 417-422

Rabot, C. 1998. Vitesse de croissance et caracteristiques lipidiques et sensorielles des muscles de poulet. $\mathrm{PhD}$ Thesis. Inst. Natl. Agron. Paris-Grignon, France.

Ramadhan, K., H. Huda and R. Ahmad. 2010. Duck meat utilization and aplication of surimi like material in further processed meat product. J. Biol. Sci. 10(5): 405-410.

Rose, S.P. 1997. Priciples of Poultry Science. CAB International. London. UK.

Ruiz, J. A., L. Guerrero, J. Arnau, M. D. Guardia and E. Esteve-Garcia. 2001. Descriptive sensory analysis of meat from broilers fed diets containing vitamin $\mathrm{E}$ or $\beta$-carotene as antioxidants and different supplemental fats. Poult.Sci. 80:976-982.

Soeparno.2005. Ilmu dan Teknologi Daging. $4^{\text {th }}$ Edition. Gadjah Mada University Press. Yogyakarta.

USDA. 2006. National Nutrient Database for Standard Reference, release 19. http://www. nalusde.gov/fnic/foodcomp/cgibin/list_nut_edit.pl. Accessed Sept. 7. 2012.

Woloszyn J, J. Ksiazkiewicz, A. Orkusz, T. Skrabka-Blotnicka, J. Biernat, and T. Kisiel. 2005. Evaluation of chemical composition of duck's muscles from three conservative flocks. Arch. Geflügelk. 69: 273-80.

Wood, J.D., R.I. Richardson, G.R. Nute, A.V. Fisher, M.M. Campo, E. Kasapidou, P.R. Sheard and M. Enser, 2003. Effects of fatty acids on meat quality: A review. Meat Sci. 66: 21-32. 